\title{
The Significance of Chinese Culture Going-out
}

\author{
Jingping Yang \\ College of Humanities and Social Sciences, Heilongjiang Bayi Agricultural \\ University, Daqing, 163319, China \\ wendy5432@163.com
}

ABSTRACT. With the implementation of China's "One Belt And One Road" national strategy, Chinese culture has risen to prominence all over the world. To promote Chinese culture going-out and expand the international influence of Chinese culture has become a new situation and new approach (Xiao Liu, 2017). But overall, Chinese culture going-out is still in a weak position and the influence of Chinese culture is not strong in the international communication. It is very important for us to speed up the pace of Chinese culture going-out.

KEYWORDS: Chinese Culture, culture elements, going-out, education internationalization

\section{Introduction}

With the development of the world multi-polarization and economic globalization, cultural diversity and advances in information age, fierce international competition of the soft power, culture has increasingly become the important engine of economic development pillar. Cultural and economic integration has become a worldwide trend. Economic globalization is accompanied by political globalization and economic globalization.

Developing countries, which are generally in a weak position, face serious challenges not only in economic development but also in cultural development. To maintain and develop the fine traditions of our national cultures, to carry forward the national spirit, to absorb the fine cultural achievements of other nations in the world and to keep up with the times are major issues concerning the future and destiny of developing countries.

\section{Definition to Chinese Culture}

For culture, there are hundreds of definitions from different perspective of views, with rich connotation and extension. Tracing back to the history, the most commonly accepted and representative definition of culture was attributed to 
Edward Taylor, a British anthropologist, who put it forward in his book Primitive Culture in 1871 that "culture is a composite whole consisting of knowledge, faith, art, morality, law, custom, and the abilities and habits acquired by any person as a member of society”.

In Chinese, culture still means a lot. The Chinese culture is extensive and profound. From the perspective of history, Chinese culture includes not only the Chinese traditional culture in the world classical culture series without interruption, but also the socialist culture guided by Marxism. The going-out Chinese culture should be the mainstream culture and advanced culture, both for thousands of years the essence of traditional culture, and including development since modern China formed the mainstream of modern culture, including the formation of revolutionary culture tradition since the May 4th Movement, the "red" culture and the beneficial culture with Chinese characteristics resulted in learning from foreign culture since the reform and opening up policy. Chinese culture plays a decisive role in the formation and development of Chinese people, mainly including the unique Chinese cultural symbols, language, calligraphy, painting, etc. The unique core values of the Chinese people, including the world view and outlook on life; The unique customs and lifestyles of the Chinese people, as well as the value orientation of life; In addition, the unique social communication and production methods of the Chinese people have formed national, collective and social cultural identity. The ideological, spiritual and emotional connotations, especially the value system accumulated over thousands of years, are the core and soul of going-out.

\section{The Current Situation of Research on Culture Going-out}

\subsection{Research on Culture Going-out abroad}

Culture going-out has gradually become a new theoretical hot issue, but the research on cultural going-out strategy has only begun in recent years. The theoretical and practical research on culture going abroad is earlier than that in China. Scholars in the fields of anthropology, cultural anthropology, international relations, cultural economics, semiotics and cross-cultural communication pay close attention to this issue. The knowledge system of these disciplines provides the most direct sources of concepts, theories and methods for the study of cultural globalization in the United States and other countries. Western anthropologists first began to pay attention to the phenomenon of cultural communication. Culture going out is a problem of cross-cultural communication in practice. Cross-cultural communication theory also emerged and developed in western countries, mainly the United States.

In the 1950s, American cultural anthropologist Edward Hall first proposed the “Cross-cultural Communication” (Intercultural Communication) concept, and after it, a group of intercultural communication research works, such as Samoyed and Potter (Samovar Larry a. \& Porter, Richard e.) of the cross-cultural communication reader, Hams (L.S.H very different), “cross-cultural Communication”, Goody Koons’s 
(W.B.G Udyknnst) of the Communication with strangers: research on cross-cultural Communication. After the 1970s, more and more scholars joined the study of this subject. As a branch of communication, cross-cultural communication studies include international communication and the interpretation of news texts in crosscultural context. In addition to paying attention to "people" in cross-cultural communication, the Chicago school scholars represented by Parker also paid attention to the differences between the two sides of communication, the social distance between people, and the open horizon brought by communication.

During late 20th century, the cross-cultural psychology and cultural psychology gradually rise, to explore the culture and perception of form, choice of culture and information, culture and understand the information, and a cultural group with another group of people thinking of the relationship between characteristics, crosscultural communication impact on individual and group psychological problems, has played a good role in promoting. These studies from the micro level for culture to go out to carry out the characteristics of cross-cultural communication, cultural conflict, cultural misunderstanding phenomenon is carried on the thorough research, mainly concentrated in the play the cultural influence of developed countries and why and how to carry out cultural output feedback effect on the implementation of crosscultural communication and its essential regularity and has carried on the theory discussion, to implement cultural foreign strategy provides better theoretical support. However, the research on cross-cultural communication in China started relatively late. In the 1970s, when cross-cultural communication became a discipline in the United States, China's external communication was still in the stage where internal publicity and external publicity could not be separated. It was not until the late 1980s that we introduced the idea of intercultural communication from abroad. In the mid 1990s, Chinese scholars' own works on cross-cultural communication appeared on the mainland. In addition, as a foreign study of the strategy of Chinese culture going global, we have to pay attention to the study of contemporary China in foreign think tanks and academia, so as to help us understand the international image of contemporary China's development. In recent years, especially with the improvement of China's comprehensive national strength and international status, foreign studies on Oriental culture and China's problems began to heat up.

It can be seen from the above research that some of the international community's understanding of China, China's problems and Chinese culture is still ideologically biased and hostile, but many of them have been more objective, positive and even forward-looking research and analysis. This has brought us both opportunities and challenges for the Chinese culture to go global, make its own voice heard and engage in dialogue with other civilizations. In the process of western culture going global, communication efficiency or the achievement of communication goals is regarded as a major indicator of communication ability. Especially foreign cross-cultural studies tend to distinguish between majority and minority, advantages and disadvantages, developed and developing, powerful and powerless, which is a way of thinking based on opposition and conflict, even for the purpose of cultural hegemony. Culture go global strategic research in China should focus on people in different culture, ethnic background, establish and develop 
harmonious cross-cultural relationship between beyond western cross-cultural attitudes and opposing, hegemony cross-cultural relations, to respect differences, seeking common ground while putting aside differences, harmonious thought to study and implement the strategy of Chinese culture to go out.

\subsection{A Brief Overview on Chinese Culture Going-out}

As for the research on the connotation of the strategy of Chinese culture going out, some people think that the export of cultural products and participation in the international cultural market competition are the main contents, while others pay attention to the issue of cultural discourse power and believe that the internationalization of cultural system and cultural standards is the core and foundation of the "culture going-out strategy".

In terms of the research on the content of Chinese culture going-out, the academic circle has conducted some research on the traditional culture going out in recent years. The existing researches are mainly carried out from the theoretical and empirical dimensions, and the theoretical researches are just beginning.

There are few conclusions about the advantages or existing experience of Chinese culture going out strategy. Most of the articles have some partial experience conclusions and some specific successful cases. However, few can be used to guide and promote the practice of Chinese culture going out to the theoretical level. In terms of works, in recent years, there has not been a special treatise on the Chinese culture going out strategy, and most of the studies on the Chinese culture going out strategy are part of other research objects.

Taken together, many experts and scholars and government officials are respectively from different angles to implement the strategy of culture going-out countermeasures are analyzed, and the better provides some ideas of strategy implementation, there are mainly attaches great importance to the operation of the national strategic level, develop the cultural industry, cultivating international talents, strengthening the cultural construction, etc., but some still remain in the perceptual knowledge stage, some articles from the level of industry and enterprise summarizes some experience worthy of promotion and cultural trade mode, didn't rise to the rational level. Most of the analysis is from a certain aspect or a certain angle, not comprehensive, not systematic, not in-depth, for example, the study of cultural strategy at the national level is still relatively little, and also lack of comprehensive analysis and combing of the cultural channels to go out.

\subsection{The Successful Case of Chinese Culture Going-out}

Literature is a mirror of the society. The Chinese novel Red Sorghum, published in 1986 was written by Mo Yan, a Chinese writer who won the Nobel Prize in Literature on October 11th, 2012. His works carry "numerous features, such as rural stories, plot twists, Chinese local characteristics and magic realism,” (Moore, 2012) and "hallucinatory realism that merges folk tales, history and the contemporary" (Li, 
2014), and his works have been "translated into more than 16 languages around the world” (Chu, 2017) Mo Yan's success attracted more publish attention on to his works, with Red Sorghum especially standing out due to the success of its movie adaptation.

The movie Red Sorghum was directed by Yimou Zhang in 1987. In 1988, the movie Red Sorghum won the Golden Bear Award at the 38th Berlin International Film Festival, the first Asian film to win this award, and other 17 awards in Zimbabwe International Film Festival, Sydney Film Festival, Brussels International Film Festival, Montreal International Film Festival, and Hong Kong International Film Festival, etc. from 1988 to 1990. (Wikipedia, Red Sorghum Film) The movie was a great success internationally.

The most influential English translation of Red Sorghum was translated by Howard Goldblatt in 1993. Howard Goldblatt is prolific and influential (Post, 2014), his translation of Red Sorghum greatly helps the spread of the original Chinese novel. "Although it has 16 versions among western countries, the English version receives the most popularity" (Ding \&Wu, 2017) "he did produce something that can be readily accepted by American readers” (Lingenfelter, 2007, p3) Mo Yan (2000) himself believes that it is Howard Goldblatt's translation that paves the way for the tremendous success of his works.

In this original Chinese novel, lots of Chinese elements have been fully described and expressed, just like the "sedan chair" which they used to carry the bride in the traditional Chinese wedding ceremony; the red coat the bride wore in the wedding and the trumpets they used to blow, etc.. Literature going-out is part of the culture going out. When we take a look at the success of this masterpiece of Mo Yan, we can easily understand that the curiosity of the people abroad. They have no idea about the history and the traditions in China, they are interested in accepting more and understanding more about the amazing country, why this country can develop at such a rapid speed.

When I tried to figure out the successful reasons for Red Sorghum going out, I found two important reasons for making the success: for one thing, the unique culture element described in the novel was the most attractive thing for the people abroad-- the Chinese peasants' life, the obedience expressed from the women and the eager to pursue freedom from their inner heart; for the other, famous translator Howard Goldblatt who was proficient in Chinese and English, also he fully understood what the audience tastes and their expectation when they read this novel. On top of that, the movie adaptation and the 18 international awards the movie gained greatly impressed people abroad a lot. Red Sorghum is a great success of Chinese culture going-out with all the factors combined together.

\section{The Significance of Chinese Culture Going-out}

"Culture is the characteristics and knowledge of a particular group of people, encompassing language, religion, cuisine, social habits, music and arts.”(Google) Culture is an important symbol of a country's "soft power". It is the cohesion and 
appeal of a country's cultural influence. It plays an increasingly prominent role in the competition of comprehensive national strength, also known as "cultural soft power". Cultural concept, ideology, values and other basic connotation of "soft power" across national boundaries of the exchange, encounter collision and fusion. "Soft power" is the counterpart of "hard power", which was first proposed by economic Professor Joseph Nye in the late 1980s. He believed that "soft power" refers to the intangible spiritual force that can influence the will of other countries, including the attraction of political system, the appeal of values, the appeal of culture, the persuasive power of diplomacy, international credibility and the charm of leaders and national images. (Yiping Zhang, 2006:54, 55) Soft power is a kind of "indirect use of power" and "assimilative power". It is the highest level of victory and the essence of national strategy. (Wennian Pan, 2010:1)

Culture has always been an important factor in a country's competitiveness. Having strong "cultural soft power" means winning the initiative in fierce international competition. Without cultural soft power, there would be no connotation, no support, just a physical shell. It's called a real power. The globalization of cultural communication has become a social reality that cannot be ignored. (Wen $\mathrm{Xu}, 2013: 96)$ "Globalization is at the center of modern culture and cultural practice is at the center of globalization." (Tom Linson, 2007:129) "Globalization encompasses pressures that force representatives of societies, civilizations, and traditions -- both 'hidden' and 'invented' -- to turn to the global cultural scene for ideas and symbols that are considered relevant to their identity". (Roland Robertson, 2000:67)

Different countries, nations and cultures all have the needs to communicate with different cultures, so that cultural communication can break through the original national boundaries and geographical restrictions, eventually get rid of the narrowness and prejudice of national cultures, and gain recognition on a global scale. In our fast changing world, we do have lots of communication and it is very important for people to know each other, to communicate and share more with each other and during this process, people can know each other better and know their culture better. China as a big country in the east, its diversity cultures and its 5,000 long history will definitely catch more people's attention.

Culture is a culture shock at the same time, however, different cultural forms, under the impact of globalization will form the international exchange and the impact, vulnerable to heterogeneous culture huge impact even submerged and especially for the weak culture, in the face of the impact of a strong culture, often has proven almost no era of globalization makes cultural hegemony has become a reality can not be ignored.

The strategy of Chinese culture going-out is a cultural development strategy based on the highest principle of China's national interests and the common interests of mankind. Is in the context of globalization, the Chinese government in the current period of important strategic opportunities, at the national level for coordination and overall planning, give full play to the government and private, domestic and overseas and so on various aspects strength, concentrated resources advantage of the 
country, the culture to go out strategy and diplomacy, education, talent strategy, in a concerted effort to promote Chinese culture going out which will make a great contribution to the world cultural prosperity and progress of human civilization.

\section{Conclusion}

To sum up, the research on the strategy of Chinese culture going-out has gained a certain foundation from the government to the academia, accumulated some experience and formed some consensus. But the deep reasons that hindered the Chinese Culture going-out are still under discussion and need to have a comprehensive analysis. We still lack system of further research and exploration on the content of the Chinese culture going-out strategy, channel strategy implementation, strategic planning, strategic goals and strategic guiding ideology. According to the current research results, compared with the interdisciplinary perspective of foreign studies, Chinese scholars' research on the strategy of cultural going out is still at the level of publicity and countermeasures, and theoretical discussions are still rare.

\section{Acknowledgments}

This research was financially supported by the Ecological Research of Western Network Literature from the Perspective of New Media (Project No. 14D046) and Research on Internationalization of Foreign Language Talent Cultivation in Agricultural Colleges and Universities -- a Case Study of Heilongjiang Bayi Agricultural University (Project No. wy2016081-c)

\section{References}

[1] Joseph S. Nye Jr, (2004). Soft Power: The Means to Success in Word Politics, New York: Public Affairs, p.25.

[2] Edward W. Said, (1993). Culture and Imperialism, VANTAGE BOOKS, New York.

[3] David Harrison, (2001). Oct 2007. A world empire by other means-The Triumph of English, The Economist.

[4] Evelyn Hamilton, (2003). International Educational Exchange: The Best Defense, Black Issues in Higher Education, Vol.20, p.34.

[5] Hall, Edward T, (1976). Beyond Culture, New York: Doubleday, p.53.

[6] Venuti Lawrence, (1994). The ‘Translators’ Invisibility: A History of Translation, London: Routledge, p.20.

[7] De Wit Hanson, (1995) Strategies for Internationalization of Higher Education: A Comparative Study of Australia, Canada, Europe and the United States of America, Amsterdam: European Association for International Education, p.11.

[8] GA. Cano (ed.), (2000). Culture, Trade and Globalization:Questions and Answers, UNESCO Pubishing 
[9] Huimin Qu, (2012) Research on Chinese Culture Going-out Strategy, Doctoral Dissertation

[10] Yiping, Zhang. (2006) Connotation and Extension of Soft Power [J]. Modern international relations, (11): 54-55. 